\title{
Sickle cell disease, part 1: Understanding the condition
}

\author{
Sickle cell disease (SCD) is one of the most common genetic blood disorders in the world \\ and effects approximately 12500 individuals in the UK. This article looks at the definition \\ of SCD, symptoms and treatments, and practical tips to prevent sickle cell crises.
}

\begin{abstract}
ickle cell disease (SCD) is a group of genetic disorders that affect haemoglobin. This is the molecule in red blood cells that delivers oxygen to cells throughout the body. People with SCD have atypical haemoglobin molecules called haemoglobin $\mathrm{S}$, which can alter red blood cells into a sickle or crescent shape (Serjeant and Serjeant, 2001). In Britain it is most common in people of African or Afro-Caribbean descent but may also occur in people from India, Pakistan, the Middle East or eastern Mediterranean. An estimated 12500 individuals live with SCD in England (Sickle Cell Society, 2008).
\end{abstract}

\section{Genetic inheritance}

Sickle cell disease is an autosomal recessive genetic disorder. For the disease to manifest a person must inherit two copies of the sickle cell gene-one from each parent. People who inherit a sickle cell gene from one parent and a normal gene from the other have a condition called sickle cell trait ( $\mathrm{Hb}$ AS). They do not have the disease but they possess one of the genes that causes it and can therefore pass this gene to their children. For example, if one parent has sickle cell anaemia and the other is normal all of the children will have sickle cell trait. When both parents have sickle cell trait they have a $25 \%$ chance of having a baby with sickle cell disease at every pregnancy (Serjeant and Serjeant, 2001; Oni at al, 2006).

\section{How does sickling happen?}

Normal red cells are biconcave, soft and flexible. They maintain their shape as they pass through the capillaries and release oxygen to the peripheral tissues. However, when sickle haemoglobin releases oxygen in the peripheral tissues the molecules tend to stick together and form long chains or polymers. The polymer is a rope-like fibre that aligns with others to form a bundle distorting the red cell into classic crescent or sickled forms. The problem is not simply one of abnormal shape as the deformed cells are rigid. They block the flow of cells and interrupt the delivery of oxygen to the tissues causing ischemia, pain and tissue damage (Bain, 2002; Stuart and Nagel, 2004) (Figure 1).

\section{Types of sickle cell disease}

There are different types of sickle cell disease. The most common are Haemoglobin SS or sickle cell anaemia,
Haemoglobin SC disease, and Haemoglobin sickle betathalassaemia (Table 1).

Thalassaemia genes produce normal haemoglobin but in variably reduced amounts. If the gene produces no normal haemoglobin, which is sickle beta zero thalassaemia, the condition is virtually identical to sickle cell anaemia. Some patients have a gene that produces a small amount of normal haemoglobin, which is sickle beta plus thalassaemia, that tends to result in a mild form of sickle cell disease. Sickle betathalassaemia is the most common sickle syndrome seen in people of Mediterranean descent such as Italians, Greeks and Turks (Franklin, 1990; Bain, 2002; Oni et al, 2006; Sickle Cell Society, 2008).

\section{Symptoms}

The severity of symptoms varies between patients. Some people have mild symptoms while others are frequently hospitalized for the treatment of more serious complications. However, the basic problem is the same; namely, the sickle-shaped red blood cells tend to get stuck in narrow blood vessels which blocks the flow of blood. This results in the following conditions:

\section{Anaemia}

The anaemia in sickle cell disease is caused by red cell destruction or haemolysis. Normally red blood cells live for about 120 days before new ones replace them. Sickle cells usually die after about 10-20 days. The bone marrow cannot make new red blood cells fast enough to replace the dying ones. Anaemia can cause shortness of breath, fatigue, and delayed growth and development in children. The rapid breakdown of red blood cells may also cause yellowing of the eyes and skin which are signs of jaundice (Franklin, 1990; Serjeant and Serjeant, 2001; Sickle cell Society, 2008).

Gulen Addis is Senior Lecturer, Faculty of Society and Health, Bucks New University, 108 Oxford Road, Uxbridge UB8 1NA

Key words

Sickle cell Anaemia Vaso-occlusive crisis

Treatment Children Young people 


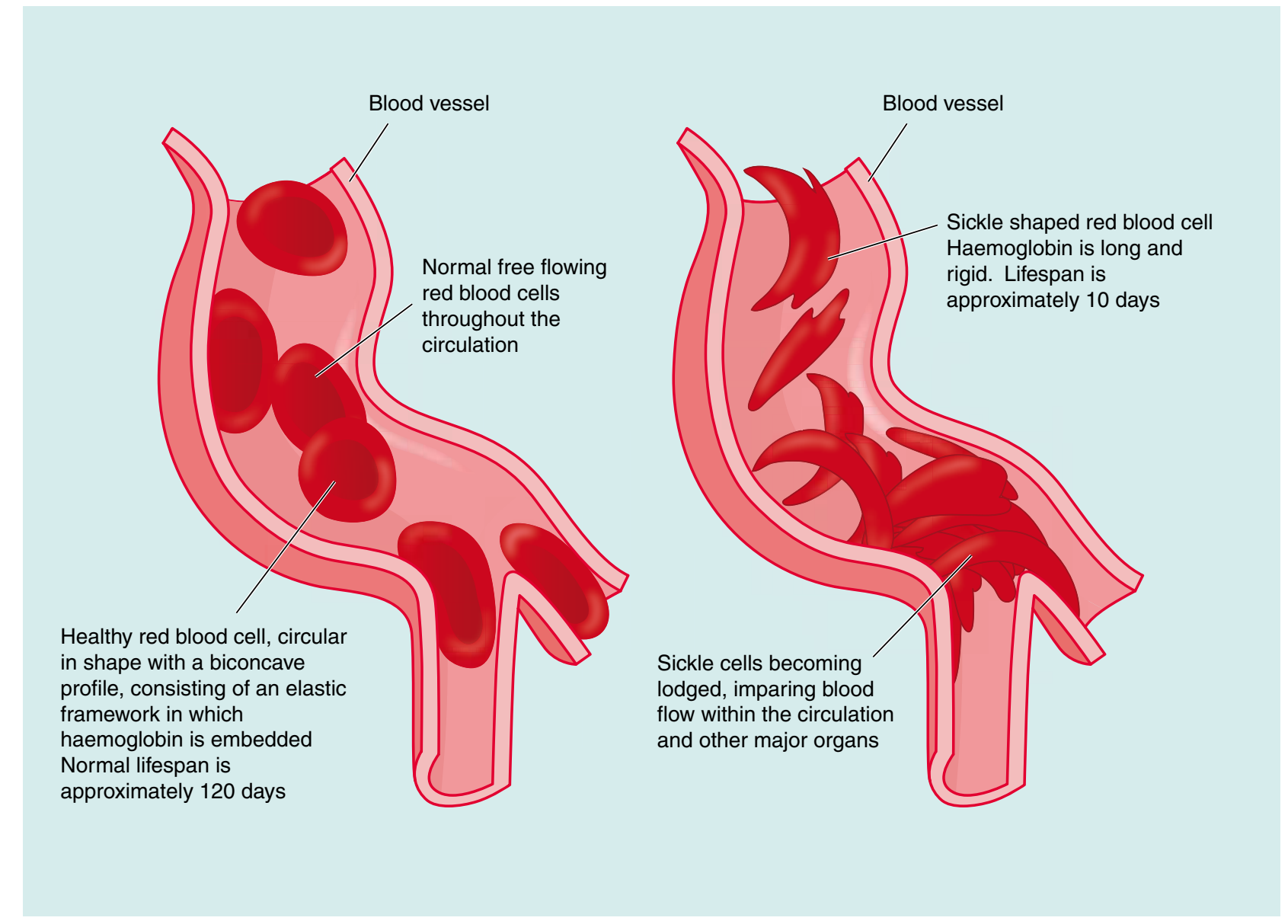

Figure 1. Examples of blodd vessels with normal red blood cells and sickle shaped red blood cells.

\section{Table 1. Examples of some common types of sickle cell disease}

\section{Sickle cell anaemia}

Sickle cell anaemia is the most common form of sickle cell disease and it occurs if a person inherits the haemoglobin $S$ gene from both parents. This type tends to be the most serious of the sickle cell conditions.

\section{Haemoglobin SC disease}

Haemoglobin SC disease occurs if a person inherits $\mathrm{Hb} \mathrm{S}$ from one parent and $\mathrm{Hb} \mathrm{C}$ from another. On average patients with haemoglobin SC disease have milder symptoms than do those with sickle cell anaemia. Some people with haemoglobin SC disease have a condition that is as severe as any patient with sickle cell anaemia.

\section{Sickle beta-thalassaemia}

Sickle beta-thalassaemia occurs if a person inherits a gene for haemoglobin $S$ from one parent and a gene for beta-thalassaemia from the other.

\section{Vaso-occlusive crises (sickle cell crises)}

The most common clinical manifestations are painful crises as a result of blockage of small vessels and tissue infarction. These account for more than $90 \%$ of all hospital admissions (Platt et al, 1991).

There is enormous variation in the number of crises patients have each year. Some patients have painful crises less than once per year while others have as many as 10 or more episodes (Franklin, 1990; Platt et al, 1991). An average sickle cell crisis usually lasts $4-7$ days if there are no complications (Davis at al, 1997). The crisis can come out of nowhere or there can be some precipitating factors, such as dehydration, infection, stress, exposure to extreme temperatures, hypoxia, and strenuous exercise. Repeated crises ultimately result in organ damage and almost any organ can be affected. Other common clinical complications include (Stuart and Nagel, 2004; Sickle Cell Society, 2008):

- Splenic sequestration

- Sepsis, acute chest syndrome

- Priapism (painful erection)

Lung disease

Leg ulcers

- Avascular necrosis on the bones

Kidney damage

Gallstones 
Proliferative retinopathy leading to progressive visual loss

- Stroke.

\section{Treatment}

Sickle cell disease does not have a widely available cure. However, treatments for the symptoms and complications of the disease exist. Bone marrow transplant may offer a cure in a small number of cases. There is some research about gene correction in sickle cell disease (Vichinsky, 2002; Perumbeti and Malik, 2010). Treatment of the complications often includes antibiotics, pain management, intravenous fluids and blood transfusion. Like all patients with chronic diseases they are best managed in a comprehensive multi-disciplinary programme of care.

\section{Prevent infections}

In general children and adults with sickle cell anaemia are more vulnerable to infections and have a harder time fighting them off. This is the result of spleen damage from sickled red cells, which prevents it from destroying bacteria in the blood. Giving oral penicillin twice a day beginning at 2 months old can prevent pneumococcal infection and early death. Vaccinations against pneumococcal infections, meningitis, hepatitis and flu are also important (Oni et al, 2006).

\section{Pain management}

Pain caused by sickle cell disease can be acute, chronic or a mixture of the two, and patients should be treated accordingly. Acute vaso-occlusive pain is the most common pain in sickle cell disease and is usually treated with a combination of anti-inflammatory agents and opioid or non-opioid analgesics. There are no objective measurements of the severity of pain and analgesia should be titrated against the patient's reported pain. The severity of pain in sickle cell disease can vary enormously thereby requiring a number of different approaches. Ideally the choice of drug should be influenced by an individual's analgesic history and some patients may carry cards with details of their ideal analgesic regimen (Okpala and Tawil, 2002; Rees et al, 2003). Paracetamol and non-steroidal anti-inflammatory drugs (NSAIDs) are appropriate for mild to moderate pain. If they are not effective then oral or parenteral opiates can be used. Patients can also benefit from some non-pharmacological approaches such as psychological support, massage, acupuncture, and transcutaneous electrical nerve stimulation.

Distraction and entertainment can be valuable and include television, video games, repeating inspirational phrases, and mental calculations. Studies have suggested that cognitive behavioural therapy for chronic pain can teach patients coping strategies that are also useful for acute pain (Thomas et al, 2001).

It is also important to treat predisposing elements alongside the management of pain. Factors such as diet, poor housing, inadequate heating, lack of education,

\section{Table 2. Practical advice}

\section{Preventing sickle cell crises in school children:}

Make the teachers and other staff aware of sickle cell disease.

Painful episodes may be prevented by not allowing a child to become over heated or exposed to cold temperatures. A child should always be kept dry and warm.

Prevent dehydration and encourage plenty of fluid consumption. Let the child have a water bottle with them or allow frequent water breaks. Extra fluid intake and the fact that the kidneys are sometimes affected by sickle cell disease means the child may need bathroom breaks more often than usual. Teachers should be made aware of this.

Avoid strenuous activities. Anaemia can cause a child with sickle cell disease to tire before others and a rest period may be appropriate. Encourage participation in gym and sports activities but allow a child to stop without attracting undue attention.

- A child should only swim in a heated pool and get dry immediately upon coming out. In some cases swimming should be avoided altogether.

A child may be absent because of severe pain episodes which can require hospital admission. Support should be given for school work during hospital stays caused by prolonged complications. Children need to go to hospital regularly for follow up.

Children may have a shorter stature and delayed puberty. The slow rate of growth is caused by a shortage of red blood cells. Taking the vitamin folic acid daily helps to make new red cells.

Sickle cell disease does not affect intelligence but various problems arising from this lifelong illness may impair academic performance. These should be identified and addressed as they would for any child with difficulties.

Sources: The Sickle Cell Information Centre, 2002; The Learning Trust, City and Hackney Teaching Primary Care Trust, 2006; Oni et al, 2006

poor access to expert services, and lifestyle choice may contribute to crises (Westerdale and Jedege, 2004).

\section{Blood transfusion}

Although anaemia is a constant feature of sickle cell disease, transfusion is rarely justified for chronic anaemia alone. Transfusion may be required in sickle cell disease either as an emergency measure or to prevent short and long-term complications. Transfusion therapy should be used judiciously because of risks such as:

- Iron overload

- Exposure to hepatitis

- HIV and other infectious agents

Alloimmunization

Induction of hyperviscosity

Limitations on resources.

Transfusion can either be a simple top up or a blood exchange depending on the complications and available resources. The indications for having a blood transfusion 


\section{Key Points}

The most common types of sickle cell disease are Haemoglobin SS or sickle cell anaemia, Haemoglobin SC disease, and Haemoglobin sickle beta-thalassaemia.

School nurses need to be well-informed about the condition in order to be able to offer students and their families the best possible support.

School nurses can help spread awareness of the condition by inviting a speaker from their local sickle cell centre or clinic to educate the entire class and/or the staff about sickle cell disease. They can also become involved in public awareness events.

Other ways in which they can help include: encouraging blood donations and drives in your community as many sickle cell patients need transfusions, supporting sickle cell research aimed at providing new treatments.

or exchange are recurrent painful vaso-occlusive crises with long hospital admissions, acute chest syndrome, stroke, priapism, and leg ulcers. Blood transfusion or exchange also can be performed before major operations, such as hip replacement because of avascular necrosis of the hip bone (Vichinsky, 2002; Sickle Cell Society, 2008).

\section{Hydroxyurea}

Hydroxyurea is a safe and effective therapy for children and adults with sickle cell anaemia. It mainly works by increasing the level of fetal haemoglobin in the red blood cells thereby reducing the concentration of sickle haemoglobin and sickling itself (Charache et al, 1995; Vichinsky, 2002). Research shows that patients receiving hydroxyurea had a lower incidence of painful events and acute chest syndrome as well as a reduced need for transfusion and hospitalization compared to those receiving no treatment (Charache et al, 1995; Kinney et al, 1999). Hydroxyurea can be used as an alternative to regular blood transfusion.

Some practical advice on how to help prevent sickle cell crises in school children can be found in Table 2 .

\section{Conclusion}

It is important that school nurses have a good understanding of the condition to be able to offer the best possible support and information to the child or young person affected by the condition, peers, parents or carers, and other school employees.

BJSN

\section{Conflict of interest: None declared}

Bain B (2002) Blood Cells: A Practical Guide. 3rd edn. Blackwell Science Limited, Oxford

Charache S, Terrin M, Moore R et al (1995) Effect of Hydroxyurea on the Frequency of Painful Crisis in Sickle Cell Anaemia. N Engl J Med 332(20): 1317-22

Davis H, Moore RM, Gergen PJ (1997) Cost of Hospitalisations Associated with Sickle Cell Disease in United States. Public Health Reports 112(1): 40-3

Franklin I (1990) Sickle Cell Disease: A Guide for Patients, Carers and

\section{Further information}

\section{Sickle Cell Society}

The Society's mission is to enable and assist individuals with a sickle cell disorder to realise their full economic and social potential. This is achieved by improving opportunities for sickle cell affected individuals and families by raising public awareness through education, advocacy together with the provision of direct welfare services, assisting in research and lobbying.

Contact details:

Sickle Cell Society, 54 Station Road, London, NW10 4UA, United Kingdom

Tel: 02089617795

Fax: 02089618346

Email: info@sicklecellsociety.org

\section{Useful resources}

The Learning Trust, City and Hackney Teaching Primary Care Trust (2006) Sickle cell disorder: A guide for teachers and carers of children. www.hackney.gov. uk/pj26318-a5sicklecell4.pdf (accessed 28 may 2010)

The Sickle Cell Information Centre (2002) Sickle cell information for teachers, students, and employers. www.Scinfo.org/teacher.htm (accessed 28 may 2010)

Health Workers. Faber and Faber, London

Kinney T, Helms R, O'Branski E et al (1999) Safety of Hydroxyurea in Children with Sickle Cell Anaemia: Results of the HUG-KIDS Study, a Phase I/II Trial. Blood 94(5): 1550-4

Okpala I, Tawil A (2002) Management of Pain in Sickle Cell Disease. J $R$ Soc Med 95(9): 456-8

Oni L, Dick M, Smalling B, Walters J (2006) Care and Management of Your Child Sickle Cell Disease: A Parent's Guide. 2nd edition. The NHS Sickle Cell and Thalassaemia Screening Programme, London

Perumbeti A, Malik P (2010) Genetic correction of sickle cell and Betathalassaemia: Progress and new perspective. ScientificWorldJournal 13(10): 644-54

Platt O, Thorington B, Brambilla D et al (1991) Pain in Sickle Cell Disease: Rates and Risk Factors. N Engl J Med 325(1): 11-6

Rees D, Olujohungbe A, Parker N, Stephens A, Telfer P, Wright J (2003) Guidelines for the Management of the Acute Painful Crisis in Sickle Cell Disease. British Journal of Haematology 120(5): 744-52

Serjeant G, Serjeant B (2001) Sickle Cell Disease. 3rd edn. Oxford University Press, Oxford

The Learning Trust, City and Hackney Teaching Primary Care Trust (2006) Sickle cell disorder: A guide for teachers and carers of children. www.hackney.gov.uk/pj26318-a5sicklecell4.pdf (accessed 28 May 2010)

The Sickle Cell Information Centre (2002) Sickle cell information for teachers, students, and employers. www.Scinfo.org/teacher.htm (accessed 28 May 2010)

Sickle Cell Society (2008) Standards for the Clinical Care of Adults with Sickle Cell Disease in the UK. Sickle Cell Society, London

Stuart M, Nagel R (2004) Sickle cell disease. Lancet 364(9442): 1343-60

Thomas V, Gruen R, Shu S (2001) Cognitive-Behavioural Therapy for the Management of Sickle Cell Disease Pain: Identification and Assessment of Costs. Ethn Health 6(1): 59-67

Vichinsky E (2002) New Therapies in Sickle Cell Disease. Lancet 360(9333): 629-31

Westerdale N, Jegede T (2004) Managing the Problem of Pain in Adolescents with Sickle Cell Disease. Prof Nurse 19(7): 402-5 